\title{
Evacuated Blood Specimen Collection Tube
}

National Cancer Institute

\section{Source}

National Cancer Institute. Evacuated Blood Specimen Collection Tube. NCI Thesaurus. Code C113124.

A blood collection tube that contains a vacuum, allowing it to draw blood through a needle to fill the tube. 